\title{
Land rents and ecological management: a note on the River Oder in 1997
}

Citation for published version (APA):

Backhaus, J. G. (1998). Land rents and ecological management: a note on the River Oder in 1997. METEOR, Maastricht University School of Business and Economics. METEOR Research Memorandum No. 006 https://doi.org/10.26481/umamet.1998006

Document status and date:

Published: 01/01/1998

DOI:

10.26481/umamet.1998006

Document Version:

Publisher's PDF, also known as Version of record

\section{Please check the document version of this publication:}

- A submitted manuscript is the version of the article upon submission and before peer-review. There can be important differences between the submitted version and the official published version of record.

People interested in the research are advised to contact the author for the final version of the publication, or visit the DOI to the publisher's website.

- The final author version and the galley proof are versions of the publication after peer review.

- The final published version features the final layout of the paper including the volume, issue and page numbers.

Link to publication

\footnotetext{
General rights rights.

- You may freely distribute the URL identifying the publication in the public portal. please follow below link for the End User Agreement:

www.umlib.nl/taverne-license

Take down policy

If you believe that this document breaches copyright please contact us at:

repository@maastrichtuniversity.nl

providing details and we will investigate your claim.
}

Copyright and moral rights for the publications made accessible in the public portal are retained by the authors and/or other copyright owners and it is a condition of accessing publications that users recognise and abide by the legal requirements associated with these

- Users may download and print one copy of any publication from the public portal for the purpose of private study or research.

- You may not further distribute the material or use it for any profit-making activity or commercial gain

If the publication is distributed under the terms of Article $25 \mathrm{fa}$ of the Dutch Copyright Act, indicated by the "Taverne" license above, 
4 March 1998

Land Rents and Ecological Management: A Note on the River Oder in 1997

\author{
Prof. Dr. Jürgen G. Backhaus \\ Maastricht University, AE \\ P.O. Box 616 \\ 6200 MD Maastricht \\ The Netherlands \\ tel: $+31-43-3883652 / 3636$ \\ fax: +31-43-3258440 \\ email: f.schijlen@algec.unimaas.nl
}




\begin{abstract}
In drawing on modern finance theory, this note demonstrates the importance of financial instruments for large public sector projects. An explicit link to the theory of Henry George is made, and a public sector financing approach is being demonstrated by using the example of the Oder floodings in 1997.
\end{abstract}

J.E.L. G12, H54 
Immediately after the conclusion of the peace of Hubertusburg between Austria and Prussia in 1763, Frederic II of Prussia set out to resume a task which he had already started as a crown prince and for which he had been scolded by his father: claiming wetlands by building dykes and dams along the river Oder, later also along the rivers Warthe, Netze and Plöne and draining these marshes along with the lake Madue. Similarly, a system of canals connecting most of these rivers with the rivers Spre and Havel was being put in place.

The peace of Hubertusburg, of course, had concluded the bitter war between Prussia and Austria, which gave Prussia most of Silesia, in particular the mountain tops. This point is relevant since, who controls the mountain tops also controls the lowlands downstream from an ecological point of view, which was very well understood by Frederic and his civil engineers and foresters. The Silesian and Moravian mountain tops need to be forested, as the occassional heavy summer rains will let the rivers swell and flood the lower marshes right before harvest time. Hence, in order to control the river, not only are dykes, dams and ditches and canals needed in the lowlands, but heavy and well-maintained forestation in the mountains, as the forests act like a sponge absorbing large amounts of rainfall while being in full foliage.

In the summer of 1997, the Oder valley experienced an almost unprecedented flood. By calling in the army (exhibit 1), the German government prevented the dykes from bursting, yet massive floods occurred in neighbouring Poland, as the river Oder is now the border between Germany and Poland. Similar floodings occurred in the Czech Republic, Romania etc. The flooding had all characteristics of a national emergency (exhibit 2), a special stamp was issued, 
a special decoration invented for volunteers, and a staggering amount in excess of 120 million German Marks being collected in private donations from German citizens of which at least 50 million German Marks were handed over to Polish charities.

The emergency occurred not only due to poor maintainance of dykes and dams under state socialism, nor only due to luvial rain fall, but in particular due to the neglect of forestation in the Silesian and Moravian mountains. Hence, preventing future floods will involve not only repairing and improving dykes and dams as well as the irrigation systems, but also and most importantly the re-forestation and proper forest maintainance in the Silesian and Moravian mountains.

As a consequence of drawing border lines during and after the second World War, both the mountain tops and the rivers Oder and Neisse have become frontier lines, which implies that ecological entities have been di-sected. Hence, what as a consequence of the Silesian war had become both an ecological and a political entity, the Kingdom of Prussia enclosing the relevant parts of the river Oder and most of its tributaries as well as the relevant mountain tops, has now lost its concomitent political authority to enforce the proper ecological management. Likewise, since the relevant jurisdiction has been lost, the tax base has been lost likewise that could allow for the clean up effort of re-building dykes and the re-forestation of the mountains needed in order to repair the damage and prevent future flooding. 
A solution to this problem can be found in the writings of Henry George ${ }^{1}$. The funds required for the repair of damage, improvements of dykes, dams and ditches and the re-forestation of the mountain tops are available in the value of the improvements of lands thereby achieved. These improvements would accrue to the owners of land as an increase in the land rent without their own labor, and hence, according to the precepts of Henry George's "remedy", they would be subject to his single tax.

Since no political authority presently exists that could levy the tax (exhibit 3), a substitute solution is being called for. Through an international treaty, an Oder Authority can be set up, with very much the same statutes as the German-Polish Foundation. Its purpose would be the ecological management of the river including the maintainance of dykes and the re-forestation and forest management of the mountain ridge. To this end, it would have to acquire land and manage it, generating proceeds from the exploitation of woodlands and river sites. It could reclaim the land rent increase due to its activities through a scheme of options as they are being propagated in modern finance theory.

A call option gives its owner the right to buy stock at a specified exercise or striking price. Similarly, a put option gives the owner the right to sell at (an obviously lower) exercise price. The present owner of lowlands faces the prospect of either owning land that is going to be flooded frequently or owning land that will be protected from flooding, and the difference in the value of these two types of land is attributable to the activities of the Oder Authority envisioned. Hence, the Authority can issue put and call options. It should actually have the exclusive right to do so. Farmers will be interested in selling land subject to frequent flooding and buying land protected from such peril. The authority itself controls the risk, and the value

$1 \quad$ Henry George, Progress and Poverty, New York: Appleton, 1980 (2). 
of the improvements must be at least as high if not in excess of the cost of making the improvements. Hence, the revenue source lies in selling the insurance (through put and call options) so as to assume the risk the land owners would like to discharge. Obviously, the authority will also buy up land at present market value, mortgaging it at close to $100 \%$.

In conclusion we can note that the award of the Nobel Prizes in 1997 to Myron S. Scholes and Robert C. Merton provides the solution to one of the bigger natural disasters that befell Europe during the same year.

\section{Reference:}

Henry George, Progress and Poverty, New York: Appleton, 1980 (2). 


\section{Exhibit 1:}

The picture shows resting German soldiers. The description by the Neue Zürcher Zeitung reads:

A shift of twelve hours of work at the dykes is followed with four hours of rest. This trenching rythm is beginning to show its effect on the helpers in uniform. 


\section{Exhibit 2:}

The picture shows a couple on the rooftop of its house waiting for help. 


\section{Exhibit 3:}

Also local governments would be beneficiaries of the proposed solution. The picture shows a fleet of busses of the town of Wiesenau, which could not be recovered in time. 